\title{
Sustainability and the multifunctional landscape: An assessment of approaches to planning and management in the Cairngorms National Park
}

\author{
Aileen Stockdale ${ }^{\mathrm{a}, *}$, Adam Barker $^{\mathrm{b}}$ \\ a School of Planning, Architecture and Civil Engineering, Queen's University Belfast, David Keir Building, Stranmillis Road, Belfast BT9 5AG, United Kingdom \\ ${ }^{\mathrm{b}}$ Centre for Urban and Regional Ecology (CURE), School of Environment and Development (SED), University of Manchester, United Kingdom
}

\section{A R T I C L E I N F O}

\section{Article history:}

Received 1 October 2007

Received in revised form 27 June 2008

Accepted 2 July 2008

\section{Keywords:}

Sustainability

National parks

Planning

Partnerships

\begin{abstract}
A B S T R A C T
Upland Scotland contains some of Britain's most prized areas of natural heritage value. However, although such areas may appear both 'wild' and 'remote', these are typically working landscapes which symbolise the interdependence of nature and society. The complexity of this relationship means that management responses will need to address a multitude of potentially conflicting priorities whilst at the same time ensuring that sufficient social and institutional capital exists to allow for the promotion of landscape integrity. The introduction of national parks to Scotland in the form of the National Parks (Scotland) Act 2000 allows for a high-level of protection for designated areas in upland Scotland. Yet, whilst the recent Act outlines the statutory purpose and direction national parks should take, it allows a significant degree of flexibility in the way in which the Act may be implemented. This level of discretion allows for significant local distinctiveness within the model but also raises questions about the potential effectiveness of chosen responses. In order to assess the potential implications of a model rooted in self-determination, we provide a case study review of the institutional basis of the Cairngorms National Park along with an assessment of the strategic character of the first National Park Plan. It is argued that whilst the Cairngorms National Park Authority has developed a significant level of stakeholder engagement, the authority may struggle to bridge the policy-implementation gap. Although a number of shortcomings are identified, particular concerns relate to the potential mismatch between strategic ambition and local level capacity.
\end{abstract}

(c) 2008 Elsevier Ltd. All rights reserved.

\section{Introduction}

National parks have only recently been introduced to Scotland. The National Parks (Scotland) Act 2000 comes more than 100 years after the designation of the world's first national park in Yellowstone and some 50 years after the introduction of national parks in England and Wales. It is arguable that the provisions contained within the enabling legislation seek to promote a new phase in the evolution of national park approaches within the UK. Whilst the 2000 Act provides for the established national park aims of conservation and recreation, specific regard is also given to sustainable development. This approach represents a significant departure from the original American ideals of wilderness conservation and public ownership (Nash, 1967; O’Brian, 1999).

Calls for the promotion of sustainable development principles within protected areas have largely resulted from increased recognition of the interdependency between society and nature in

\footnotetext{
* Corresponding author. Tel.: +4428 90974771; fax: +442890663754.

E-mail addresses: a.stockdale@qub.ac.uk (A. Stockdale), adam.barker@manchester.ac.uk (A. Barker).
}

populated rural areas. In such areas, natural heritage value stems not from the separation of nature from human activity, but from continued and careful forms of environmental modification. Maintenance of this heritage is therefore dependent upon the promotion of management objectives which account for both conservation and socio-economic development (Holdgate, 1992). This approach to park management has received a significant level of support from the international community. Whilst Our Common Future (UNCED, 1987) argued for the need for 'parks for development', the Fourth IUCN (World Conservation Union) Congress on National Parks in Caracas suggested that the effectiveness of parks would require full appreciation of the cultural, political and socio-economic systems in place within protected areas (IUCN, 1992). The centrality of sustainable development to the aims of Scottish national parks suggests a clear attempt to respond to this increased emphasis upon the multi-functional dimension of natural heritage management.

Meeting the challenge of sustainable development is, however, far from straightforward. Whilst there has been significant international commitment to the development of a broader agenda for national parks, there is a significant degree of variability in the performance of national parks worldwide. The IUCN (2004) have suggested that many national parks have simply failed to develop 
the appropriate structure and direction required to operationalise sustainable development. Even in Europe, where $345,821 \mathrm{~km}^{2}$ of the land area under protection is populated, very few national parks have managed to make appropriate provisions for rural development (Zupančič-Vičar, 1997). According to McCarthy et al. (2002) and Bishop et al. (1998) most national parks still give priority to conservation of the natural environment.

One of the key debates surrounding the Scottish approach to sustainable development within national parks is the impact that local discretion will have on the structure and direction of national park planning and management. Whilst there is an element of prescription with the 2000 Act, a significant degree of flexibility is afforded to the responsible National Park Authority in determining the institutional and strategic character of the park (Barker and Stockdale, 2008). This raises concerns as to whether the level of institutional autonomy contained within the Scottish model is likely to generate sustainable development outcomes or whether there is a need for clearer guidance and direction.

As an initial response to addressing this question, this paper provides a review of the emerging approaches being developed and adopted within the Cairngorms National Park. In particular, the paper reviews the first Cairngorm National Park Plan (approved in 2006 and implemented from 2007 onwards), and considers the extent to which it, and its associated management structures, will be able to deliver its intended outputs. In order to assess the potential performance of both institutional and strategic provisions, we unpack the common thematic elements of the Cairngorms approach and locate them within a wider discussion informed by the rural management and public policy literature. Central to this discussion is the review of the partnership structures which underpin much of the responsibility for management success in the Cairngorms and the comprehensive-rational nature of policy provisions.

The remainder of the paper is structured into five main sections. We begin by considering the relationship between national parks and sustainable development goals. Here we draw particular attention to the role of landscape protection in balancing socio-economic and environmental deliverables. This is followed by a review of the shifting interpretation of the national park concept within the UK and a discussion of the manner in which sustainable development principles have been incorporated in current legislative provisions. In the third part we provide a case study evaluation of the nature of planning and management arrangements within the Cairngorms National Park. The fourth part then reviews these approaches and explores the degree to which they are likely to fulfill the overarching statutory requirements. In the last section, we draw conclusions regarding the current trajectory of the Cairngorms National Park and consider future priorities for Scottish National Parks.

\section{Towards the protection of landscape}

The definition of 'what is' and 'what is not' a national park is an area of significant debate. Even though the term 'national park' is in widespread international usage, interpretations of the national park idea vary according to national circumstances and international standards (Dower, 1999). In this part of the paper we explain the basis of the national park concept and place the Scottish interpretation of national parks in its broader context.

The origins of the national park approach can be traced to a 19th century American preoccupation with wilderness conservation and a desire to protect the great 'natural monuments' of the west (Dilsaver, 1997). This inspired the designation of Yellowstone as a national park in 1872 and enabled the creation of a "pleasuring ground for the benefit and enjoyment of the people" (Nash, 1967, p. 9). Fundamental to the American national park movement was a belief in the importance of a nature which lacked human influence and the assertion that conservation was best served through the "withdrawal' of land from settlement. It was on this basis that national parks in America became synonymous with national ownership and resource use restrictions.

The approach adopted in America has had a significant impact upon the evolution of national parks worldwide. Under criteria established by the IUCN in 1994, the term 'national park' is reserved for those areas which share the American concerns of nature conservation and recreation. These areas are referred to as Category II (Table 1) areas and are defined as:

"A natural area of land and/or sea, designated to (a) protect the ecological integrity of one or more ecosystems for present and future generations, (b) exclude exploitation or occupation inimical to the purposes of designation of the area, and (c) provide a foundation for spiritual, scientific, educational, recreational and visitor opportunities, all of which must be environmentally and culturally compatible" (IUCN, 1994).

Clearly, such a definition affords little scope for the development of national parks in the UK. Most of the UK environment is heavily modified and has long been the basis for commercial resource use activity. On this basis, national parks in the UK have deviated from the strict definitions offered by the IUCN. In Scotland in particular, national parks have evolved as mechanisms for balancing conservation and recreation with local development. Although this approach falls short of the criteria for Category II protected areas, Scottish national parks do accord with the principles established for Category V areas. These are defined as 'landscapes' or 'seascapes' where:

“. the interaction of people and nature over time has produced an area of distinct character with significant aesthetic, ecological and/or cultural value, and often with high biological diversity" (IUCN, 1994).

The Category V approach has developed in response to both the emergence of sustainable development as a paradigm for protected area management and increased awareness of the 'dynamic' nature of working landscapes. Here, landscapes are seen to merit special protection because they encapsulate the co-evolution of society and nature (Brown et al., 2005). According to Phillips (2005) and Phillips and Clarke (1996) this co-existence has generated many of the world's most valued landscapes. Such areas display not only

Table 1

Protected Area Categories (IUCN-The World Conservation Union, 1994)

\begin{tabular}{|c|c|c|}
\hline Category & Name & Definition \\
\hline I a & Strict nature reserve & Managed mainly for science \\
\hline I b & Wilderness area & Managed mainly for wilderness protection \\
\hline II & National park & Managed mainly for ecosystem protection and recreation \\
\hline III & Natural monument & Managed mainly for conservation of specific natural features \\
\hline IV & Habitat/species management area & Managed mainly for conservation through management intervention \\
\hline V & Protected landscape/seascape & Managed mainly for landscape/seascape conservation and recreation \\
\hline VI & Managed resource protected area & Managed mainly for the sustainable use of natural ecosystems \\
\hline
\end{tabular}


key aspects of biological and ecological significance but are also of fundamental cultural importance. Preserving the integrity of landscape areas must therefore be based on an appreciation of the role of local communities in the processes of landscape change.

In recognition of the contribution that the Category $\mathrm{V}$ approach can make towards sustainable development, the IUCN (2002) has published a series of sustainable development guidelines specifically relating to Category V designations. Two important themes emerge from these guidelines. First, they seek to advance management activity at the interface between people and nature by acknowledging that concentrating management effort at the point of interaction between people and place can reduce conflict. Second, the guidelines recommend the development of inter-agency partnerships and emphasise the role of local communities within protected areas. In particular, they stress the need for community empowerment and co-management. The extent to which Scottish national parks can effectively deliver sustainable development will, in part, be dependent upon awareness of the main principles which have informed this guidance.

\section{The changing nature of national parks within the UK}

Before providing a case study review of the potential performance of current national park arrangements within the Cairngorms, it is important to place this discussion within a historical framework. Although Scottish national parks display many of the same features as those in England and Wales, they represent a new stage in the evolution of UK national parks. In this section of the paper therefore, we explore the emergence of national parks in the UK and highlight the gradual transition from conservation and recreation toward the management of sustainable development.

The introduction of national parks in England and Wales originated in response to concerns regarding the unplanned development of, and the absence of public access to, particularly scenic upland areas (MacEwan and MacEwan, 1982; Rydin, 1998). In response to pressure group calls for institutional reform, the Government commissioned the Dower Report (1945). This report recommended that national parks should be established in areas of outstanding scenic and recreational importance, and broadly supported the introduction of the US model of national parks. In other words, national parks should be given over to public ownership and aim to deliver landscape preservation, public access and conservation of both wildlife and buildings (Hall, 1992).

Although Dower's recommendations were largely endorsed by the Hobhouse (1947) Committee, proposals for public ownership of national parks were ultimately rejected. The subsequent National Parks and Access to the Countryside Act (1949) therefore, was enacted with the provision that land within designated areas should remain in private ownership. According to the Act, the main functions of national parks were stated as the preservation and enhancement of natural beauty and the encouragement of public enjoyment. This enabling legislation led to the designation of the UK's first national park in the Lake District in 1955. Since then, a further eleven national parks have been designated in England and Wales (Fig. 1).

Despite an early interest in national parks in Scotland, the evolution of national parks north of the border highlights a much lengthier and more complex process than that observed in England and Wales. The Ramsay Report (1947) recommended the introduction of national parks in Scotland at the same time that Hobhouse had recommended national parks for England and Wales. However, there was both a lack of political support (McCarthy et al., 2002) and a perceived absence of need (Shucksmith and Lloyd, 1983). In particular, there was an assumption that agricultural land was unlikely to be significantly at risk from intensification and that the Scottish uplands could accommodate further levels of recreational growth without high-level intervention. A further key feature of this period was the role played by Scottish landowners. Concerned that the introduction of national parks would lead to the nationalisation of designated lands, a strong lobby emerged which put additional pressure on Government.

Debates surrounding national parks in Scotland continued throughout the remainder of the century. However, it was not until the 1990s that the debate intensified. This corresponded with a persuasive case put forward by the Countryside Commission for Scotland (CCS). It highlighted not only the need for improved approaches to land management (Crabtree, 1991; Dickinson, 1991), but also argued for the provision of social and economic well-being within national park communities (CCS, 1990). In doing so, the CCS proposal provided the first genuine UK attempt to incorporate sustainable development principles within UK national park objectives. Even though the CCS proposals were rejected at the time (Scottish Office, 1991), it is notable that the eventual legislation introducing national parks in Scotland has incorporated much of the thinking behind the report. Arguably, it was not so much the CCS proposals that led to rejection, but a failure to generate an appropriate level of political support. This changed following Scottish Devolution in 1997 when, for the first time, a clear political consensus existed for the introduction of national parks in Scotland. Although a clear management case for national parks was put forward, Warren (2002) has argued that the main driving force behind this shift in attitude was the need for demonstrable forms of national identity and a renewed sense of national pride.

To date, two national parks have been established under the National Parks (Scotland) Act 2000: Loch Lomond and Trossachs National Park (2002) and the Cairngorms National Park (2003). Section 1 of the Act requires these new designations to adhere to four primary management aims. These are:

- To conserve and enhance the natural and cultural heritage.

- To promote the sustainable use of the natural resources of the area.

- To promote understanding and enjoyment (including enjoyment in the form of recreation) of the special qualities of the area by the public.

- To promote sustainable social and economic development of the communities in the area.

Whilst several of these aims are shared with national parks in England and Wales, the specific reference to sustainable development is unique to the Scottish model. Although this is a significant development within the context of UK national parks, the Act clearly states that not all the aims are to be considered equally. In accordance with the IUCN guidance for Category $\mathrm{V}$ designations (IUCN, 2002), a dominant management aim is highlighted. Section 9 of the Act stipulates that where there appears to be conflict between the first aim - to conserve and enhance the natural and cultural heritage - and any of the other three aims, greater weight should be given to the first aim. This corresponds to the so-called Sandford Principle which emanates from the National Parks Policy Review Committee (for England and Wales) which sat 1971-1974 (Sandford Committee, 1974).

Under the terms of the 2000 Act, where a national park is designated, an independent National Park Authority must also be established. In accordance with Section 11 of the Act, the Authority is required to produce a National Park Plan. The purpose of the plan is to provide a strategic management framework which establishes guiding principles and priorities for achieving the four manage- 


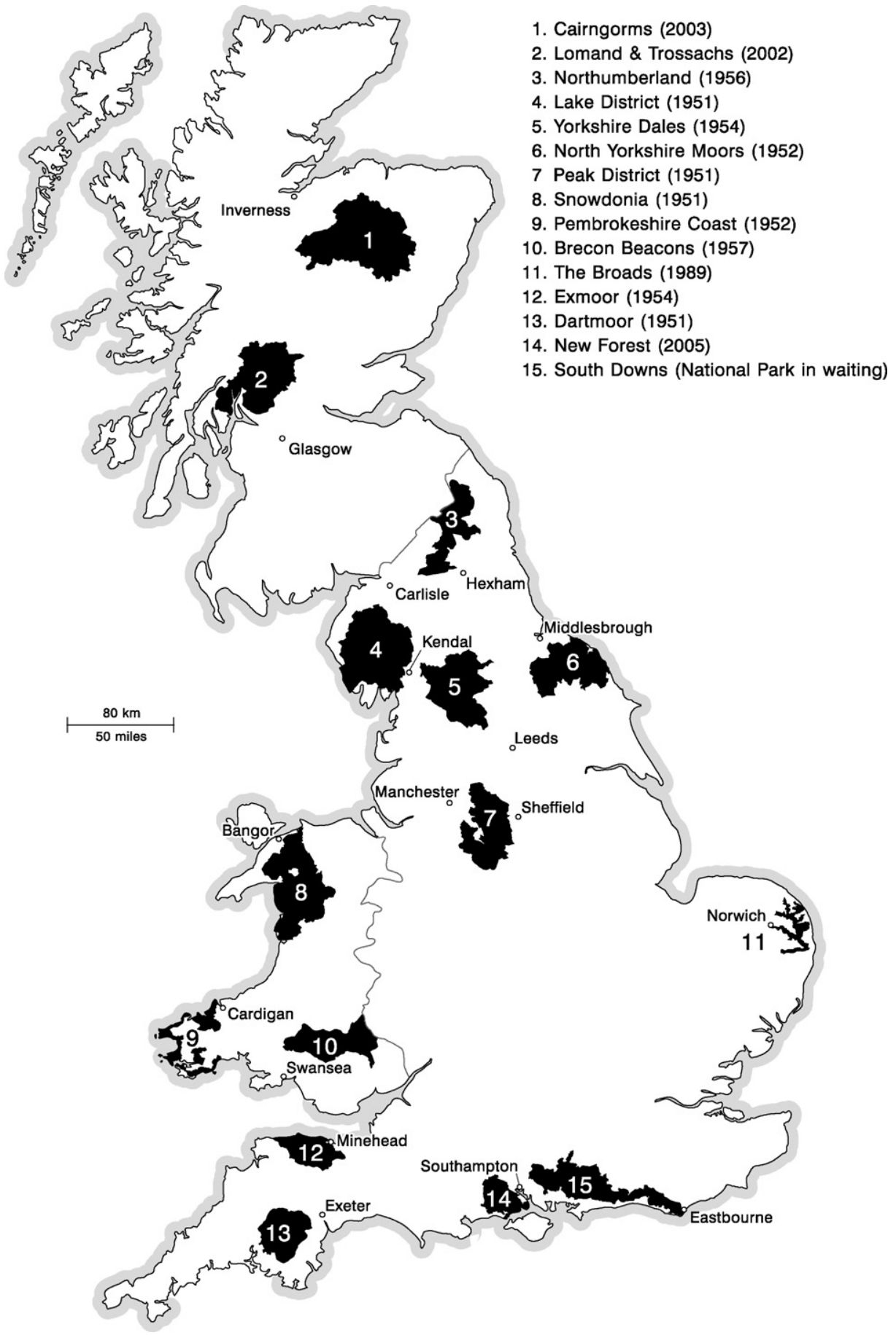

Fig. 1. UK National Parks.

ment aims stated in Section 1 of the Act. Importantly, the plan is not simply a working brief for the National Park Authority. Rather, it seeks to guide the activities of all principal stakeholders in the park.

Additionally, the Act also legislates for the National Park Authority to adopt a range of supplementary planning and management roles. These relate to:

- town and country planning;

- advice and assistance;

- grant allocation;
- management agreements;

- land acquisition;

- rights of way;

- interpretation; and

- recreation.

A central feature of the Act is that whilst it highlights the overarching management objectives that a National Park Authority must deliver, along with the powers it might adopt, it also allows for a significant degree of flexibility and interpretation. Section 9 of the Act, for instance, states that: 
"A National Park authority may do anything which it considers is calculated to facilitate, or is conducive or incidental to- a) accomplishing the purpose set out in subsection 1 [to ensure that the national park aims are collectively achieved], $b$ ) carrying out any function conferred on it by virtue of any other enactment."

This emphasis on institutional autonomy is particularly apparent in Sections 11 and 12 of the Act which outline requirements for the National Park Plan. Beyond addressing issues of plan submission, consultation and review, the respective Authority, subject to approval by the Scottish Ministers, is left free to determine plan content and direction. Under Section 17, the Act also enables the Authority to determine whether it will allow another authority to undertake any of its functions on its behalf. Finally, even though Section 16 legislates for the provision of directions and guidance by the Scottish Ministers, this asserts 'a right' rather than a 'duty' within Government. In a situation where Ministers decide no intervention is necessary, the relevant National Park Authority will be left largely to its own devices.

The level of discretion provided for by the Act also extends to National Park Designation orders. Under the terms of Section 10, it is left to individual Designation Orders to establish the precise institutional structure of the Authority. As such, there is a considerable degree of individuality concerning the structure of Scottish national parks. Two potential options are available. Firstly, a national park authority may acquire the spatial planning functions from the existing local authorities within the Park area. Such functions include the preparation of structure plans to guide development within the area, along with development control and enforcement powers. This approach corresponds with the institutional structure adopted by national parks in England and Wales. Secondly, it is possible for planning powers to remain with the relevant local authorities. Here, the role of the National Park Authority is that of statutory consultee on planning issues arising within the park boundary. Currently, the two national parks in Scotland are operating under different institutional arrangements. The Loch Lomond and Trossachs National Park (in Scotland) has adopted the former approach (as seen in England and Wales), whilst the Cairngorms National Park has adopted the latter, and with it, a unique structure amongst UK national parks. Strategic planning and development control powers remain the responsibility of the relevant local authorities (Aberdeenshire, Angus, Highland, and Moray), whilst the Cairngorms National Park Authority has responsibility for the preparation of a local plan for the Park area. ${ }^{1}$ The allocation of the planning function for the Cairngorms national park area was (and remains) a deeply contested issue (Illsley and Richardson, 2004). For example, Highland Council withdrew its objection to national parks in 1998 on the basis that any national park in the Highlands would leave the planning powers in the hands of the local authority (that is, Highland Council).

\section{A planning and management case study: the Cairngorms National Park}

After having highlighted the significance of the Scottish interpretation of national parks, we now consider the potential effectiveness of current provisions. In order to do this, we provide a case study evaluation of planning and management approaches being adopted within the Cairngorms National Park. As the Cairngorms National Park Authority (CNPA) have recently finalised both management structures and management goals, this part of the

\footnotetext{
1 A Cairngorm National Park Local Plan (CNPA, 2006d) has been prepared by the Cairngorms National Park Authority. This Plan was placed on deposit in July 2007 (CNPA, 2007b) and is to be adopted as a statutory local plan in November 2008.
}

paper provides the first analysis of the early stages of national park development in Scotland. This section is sub-divided into three parts. First we provide a contextual overview of the character of the national park and draw attention to particular management issues. Then we consider the status of current administrative structures, followed by a detailed analysis of the adopted National Park Plan.

\section{The Cairngorms National Park area}

The Cairngorms National Park (Fig. 2) covers an area of $3800 \mathrm{~km}^{2}$, making it the largest national park in the UK. If the National Park is to succeed, it will need to prove responsive to the complex nature of environmental and socio-economic systems in operation within the park boundary (Barker and Stockdale, 2008). Whilst the National Park contains some of Scotland's most prized rural assets, it is also home to a fragile rural community which is increasingly feeling the impacts of shifting economic and social preferences (Ferguson and Forster, 2005). In this part of the paper, we briefly outline the main characteristics of the case study area and indicate the changing nature of management pressures.

Much of the natural heritage importance of the Cairngorms area stems from the presence of internationally significant landforms, habitats and species (Gordon et al., 1998, 2002; Watson, 1996). The most distinctive natural feature within the Park is the extensive area of highland plateau at the centre of the Park. This is the highest area of arctic landscape anywhere in the UK and an area which is particularly susceptible to interference. This upland core is then surrounded by a varying pattern of heather clad moors, forested slopes, farmland and floodplains (Gimingham, 2002). Nearly $40 \%$ of the landmass within the Park is recognised by national or international conservation designations (including Sites of Special Scientific Interest; Special Area of Conservation; Special Protection Area; Ramsar Sites; National Nature Reserve and Geological Conservation Review) (SNH, 2001). This complex landscape however, is currently experiencing a range of physical pressures which are generated by both local inhabitants and visitors. Particular issues of concern relate to inappropriate forms of built development, landscape modification, over-grazing, habitat loss, congestion and erosion (Gimingham, 2002). Of these concerns, Ferguson and Forster (2005) identify grazing by red deer, the extension of ski facilities and the growth of bull-dozed hill tracks as the most significant examples.

The socio-economic environment presents an equal number of management challenges. The local economy has traditionally been dependent upon the primary sectors of agriculture, sporting, hunting and fishing. In the post-productive era of today's rural economy however, a diversified economic base is now evident. This combines traditional land use activities with tourism and recreation, environmental stewardship, and a shift towards an increasingly service-orientated economy (Shucksmith and Chapman, 1998; MacKay, 2005). Of the 16,000 inhabitants currently living in the Park, $19 \%$ of the population is employed in hotels and restaurants, whilst $20 \%$ are employed in public services. Although there are 570 farm holdings within the National Park, agriculture currently accounts for only $5 \%$ of direct employment (CNPA, 2006e). Not only does this highlight the degree of economic pressure currently facing those engaged in traditional land use activities, but it hints at a wider concern linked to the future landscape character of the area. As so much of the integrity of the local landscape is dependent upon the role played by the primary sector, maintaining traditional land use management practices is likely to be one of the main concerns facing the Cairngorms National Park Authority. Due to the continued importance of the highland estate within the area, management intervention will also need to recognise differences in scale and aspiration. 


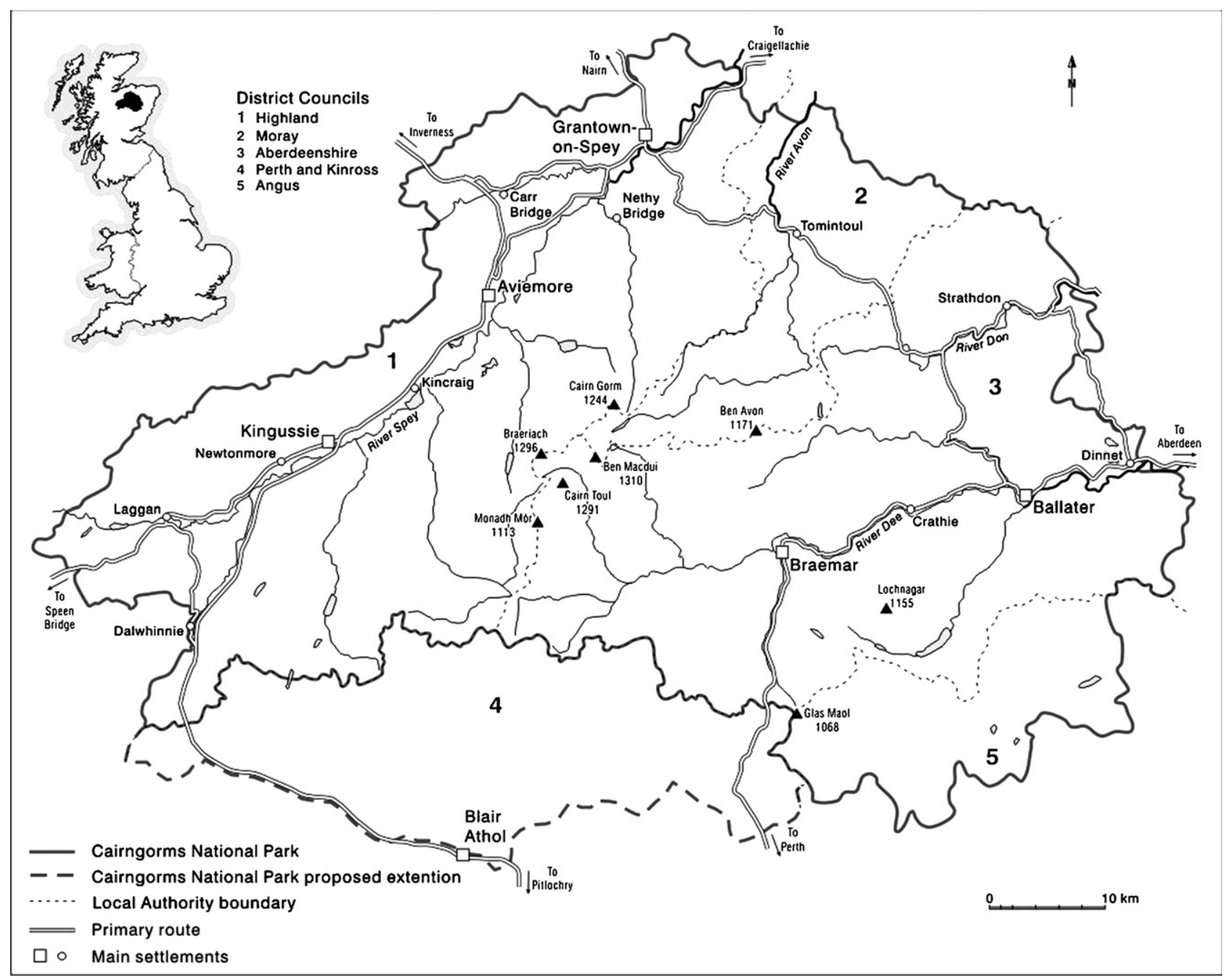

Fig. 2. Cairngorms National Park area.

The changing nature of rural society in the Cairngorms is further evidenced by the impact of tourism upon rural housing. Whilst tourism offers clear benefits to the area, a negative consequence has been the growth of second homes. Recent reports allege that there are over 1800 holiday homes within the Park boundary (The Scotsman, 2006). With a high overall threshold entry price, access to the housing market is an on-going issue. Such social pressures are further compounded by a trend towards rural ageing and a 'thinning' over the economically active sector of the population (Shucksmith et al., 1994).

\section{The Cairngorms National Park Authority}

As alluded to above, the statutory purpose of the National Park Authority is to ensure that all four aims of the park are achieved collectively and in a coordinated way. As a result, the National Park Authority has adopted the role of facilitator within a partnership structure. This accords with the collaborative approach advocated by the IUCN (2002) guidelines and with the increasing emphasis on governance within public administration (Swyngedouw, 2005). Both inter-agency and agency-community co-operation and partnership are advocated by the Authority. In encouraging the latter, five elected local members currently sit on the National Park Board. Their inclusion is intended to extend partnership working from an emphasis on the formal institutions of government to the local community as a whole. This is something which Skinner (1997) views as essential if local people are to define and achieve individual and community aspirations. Such an approach is typified by the Scottish Executive (2002) report on Building Consensus for Rural Development and Planning in Scotland.

The emphasis on co-operation and partnership is apparent throughout the planning and management process. Firstly, collaboration is sought in order to define a shared strategic vision for the Park, along with associated management objectives and priorities. Since the establishment of the Cairngorms National Park in 2003, a series of partnership meetings have been, and continue to be, organised by the National Park Authority. These have involved discussions with relevant agencies, public meetings, and themed advisory forums (for example, the Outdoor Access Forum and the Economic and Social Development Forum). Public consultation in the preparation of the Park Plan also attempted to ensure that wider views were considered (Table 2 ).

Secondly, co-operation and partnership is deemed the most appropriate mechanism to ensure the effective and efficient delivery of relevant action programmes. For example, the individual corporate plans of public bodies are expected to reflect the vision and objectives of the Park Plan, in so far as their work affects the aims of the Park. The National Park Authority will co-ordinate the 
Table 2

Participation in the Cairngorms Park Plan Public Consultation Exercise

\begin{tabular}{lc}
\hline Number of responses received & 124 \\
Number of consultation meetings & 31 \\
Number attending meetings & 588 \\
Average web page visits/per day & 243 hits \\
Number of respondents: & \\
Public bodies & $21(17 \%)$ \\
NGOs & $13(10.5 \%)$ \\
Communities & $7(5.5 \%)$ \\
Professional associations/business & $22(18 \%)$ \\
Individuals & $61(49 \%)$ \\
\hline
\end{tabular}

Source: CNPA (2006c) p. 5.

delivery of action programmes. Moreover, co-ordination will itself be overseen by an Advisory Panel on Joined-Up Government (comprising senior representatives from relevant public agencies).

Core funding for the Cairngorms National Park Authority stands at $£ 4.50$ million per annum (2007-2008). To assist the Authority to build partnerships with communities and achieve priority goals six priority schemes for grant funding have been available since 2005 (and continued for the 2007-2008 financial year). These schemes include: Investing in Communities (renamed A Park for All for 2007/2008), Marketing and Events, Biodiversity, Interpretation, Outdoor Access, and Cultural Heritage.

These schemes are all part-funded by the Cairngorms LEADER+ programme and current grants range from $£ 500$ to $£ 5,000$. The Schemes are open to voluntary groups and organisations, not individuals or businesses. For example, the Investing in Communities Scheme supports community-based projects that focus on developing and strengthening local community organisations; building the capacity of individuals and groups to contribute to community development; and encouraging and promoting participation in local action planning and community development activity.

In addition, the Cairngorms National Park Authority itself supports, runs or finances other projects that sustain the aims of the Park. These include: the Local Biodiversity Action Plan Project, the Cairngorms Moorland Project, the Cairngorms LEADER+, and a Land Based Business Training Project.

\section{The National Park Plan}

The Draft Cairngorms National Park Plan was originally published as two documents. Looking to 2030 (CNPA, 2006a) established the strategic basis of management activity over the long term, whilst Priorities for Action 2007-2012 (CNPA, 2006b) focused on the use of resources in the immediate future. The final Park Plan (CNPA, 2007a), approved by Scottish Ministers in March 2007, has retained these two-time horizons but incorporates them into one document. The defining characteristics of this adopted Park Plan are outlined below.
Table 4

Examples of partner organisations

\begin{tabular}{ll}
\hline Cairngorms National Park Authority & Cairngorms Chamber of Commerce \\
Communities Scotland & Business Associations \\
Forestry Commission Scotland & Local Enterprise Companies \\
Housing Associations & Local Biodiversity Action Plan group \\
Local Authorities & Scottish Natural Heritage \\
Scottish Executive & VisitScotland \\
Highlands and Islands Enterprise & Volunteer Development Scotland \\
Scottish Water & Scottish Civic Trust \\
Scottish Rural Property and Business & Mountaineering Council of Scotland \\
\multicolumn{1}{c}{ Association } & \\
& Historic Scotland \\
Non-Government Organisations & John Muir Trust \\
National Farmers Union (Scotland) & Deer Commission for Scotland \\
Scottish Crofting Foundation & Farming and Wildlife Advisory Group \\
& Scottish Gamekeepers Association \\
\hline
\end{tabular}

\section{Promotion of sustainable development}

In accordance with the principles established by the IUCN Category V approach, the CNPA have used the Plan to establish a vision for the Park which is rooted in an understanding of the multifunctional demands of the dynamic landscape. In particular, the CNPA (2007a) suggest that the Cairngorms National Park is an environment "....in which the natural and cultural resources are cared for by people who live there and visit" (p. 4) and which has the potential to exist as "an exemplar of sustainable development showing how people and place can thrive together" (p. 4). In order to advance this notion, the principle of sustainable development forms the first of the five related management principles established to guide policy development. These principles are summarised in Table 3. The emphasis on sustainable development which runs throughout the Plan means that, in many instances, policy objectives are expected to generate multiple outcomes at the same time. This is true, for example, in the case of those policies which address 'integrated land management'. In most cases, policy options assert the use of techniques which are both conservation led and economically productive.

\section{Partnership development}

The content of the Park Plan reinforces the partnership approach to the delivery of national park aims. As part of this approach, the Plan emphasises the importance of stakeholder diversity and makes provision for public involvement (Table 3 ). The approach is advanced by the identification of partners at each stage of the Plan hierarchy. These are drawn from a wide range of organisations in Scotland (Table 4) and include those in the public, professional and voluntary sectors. In the main, more than one partner is identified for each of the action programmes detailed in the Plan. The Plan argues that the Park's aims cannot be achieved through the work of only one or two organisations alone. This includes the CNPA. The Plan does not advocate the use of a single partnership model however. Instead, the partners involved will vary according to the

Table 3

Principles underpinning the Cairngorms National Park Plan

\begin{tabular}{|c|c|}
\hline Principle & CNPA interpretation \\
\hline Sustainable development & $\begin{array}{l}\text { Balance the needs of the people living, working and enjoying the Park with the need to conserve and enhance its natural and cultural } \\
\text { resources for future generations }\end{array}$ \\
\hline Social justice & A culture of inclusiveness that seeks to create opportunities for everyone regardless of economic, social or physical constraints \\
\hline People participating in the park & $\begin{array}{l}\text { People within and outside the Park should be actively involved in shaping the Park and its management, building their capacity to do } \\
\text { so and encouraging active citizenship }\end{array}$ \\
\hline Managing change & $\begin{array}{l}\text { Management of the Park to be informed by best available information to identify and effect positive change (and prepare for and } \\
\text { mitigate negative change) }\end{array}$ \\
\hline Adding value & $\begin{array}{l}\text { The collective efforts of all managing the Park should focus on delivering positive and tangible outcomes for the people and places of } \\
\text { the Park }\end{array}$ \\
\hline
\end{tabular}


Table 5

Partnership mechanisms

\begin{tabular}{|c|c|}
\hline Mechanism & Role \\
\hline Priority for Action Delivery Groups & To deliver and report progress on the actions necessary to achieve the priorities for action outcomes \\
\hline National Park Advisory Forums & To advise on the implementation of the Plan's aims \\
\hline Advisory Panel on Joined-up Government & To co-ordinate the role of the public sector \\
\hline Forward Strategy Group & To monitor the state of the Park, identify and advise on drivers of change, strategic research and forward planning. \\
\hline
\end{tabular}

Source: CNPA (2007a) p. 122.

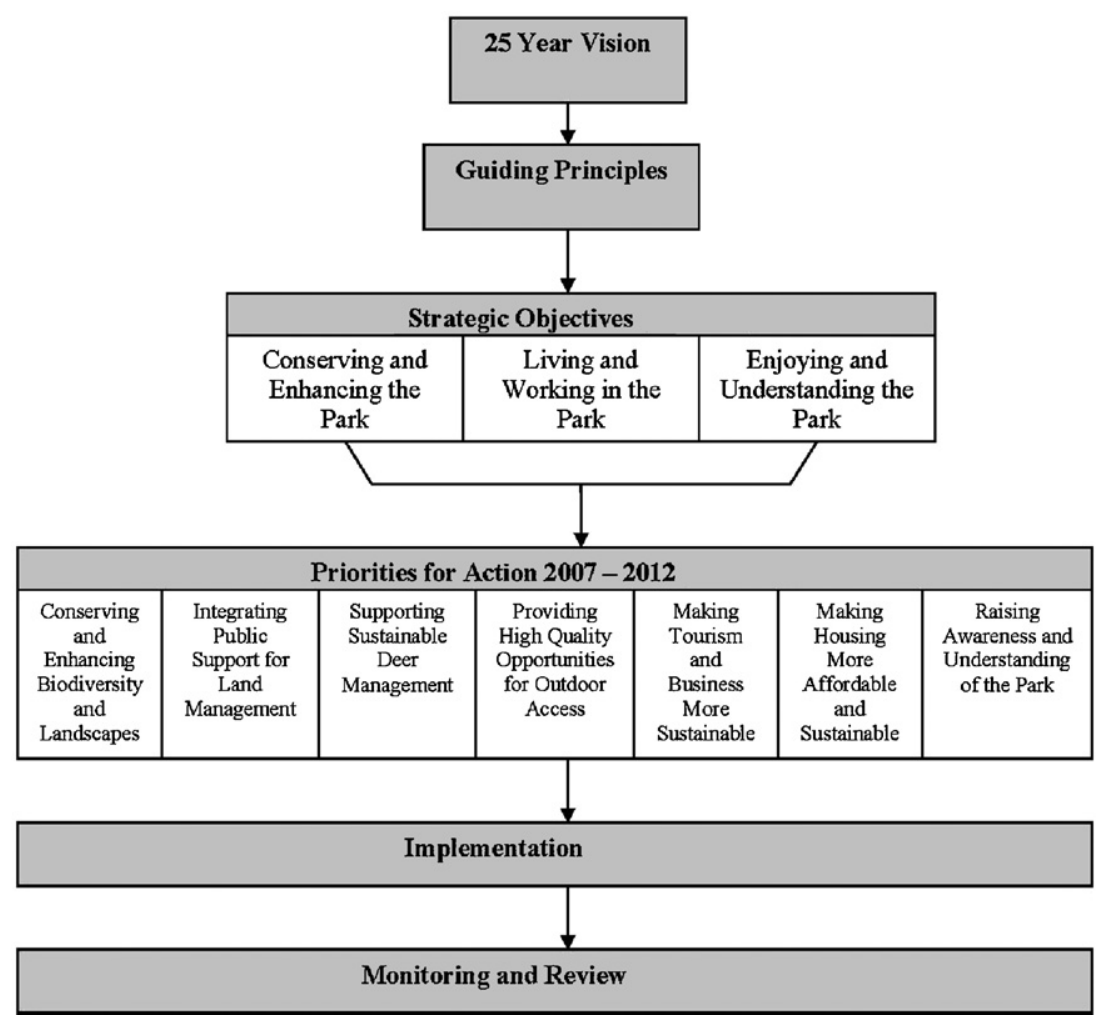

Fig. 3. Structure of the Cairngorms National Park Plan.

subject matter in hand. The formal mechanisms currently identified to bring partners together are outlined in Table 5.

\section{Strategic tiering}

To aid the realisation of the Park's vision and aims, the Plan (and accordingly the approach to national park management) adopts a hierarchical policy arrangement. It comprises a series of management layers which are intended to cascade from strategic vision through to implementation. The Plan does not however, indicate how this might occur. The key attributes of the layers that make up the plan framework are briefly discussed.

First, the Plan identifies three broad strategic headings (Fig. 3). These are consistent with the statutory national park aims of conserving and enhancing the Park; living and working in the Park; and enjoying and understanding the Park. The heading-living and working in the Park, for example, acknowledges the opportunity to build on the established links which already exist between the economy, the natural environment and communities within the park. In particular, the CNPA (2006a) suggest that:

".the integration of these interests should ensure that economic development builds on the special qualities of the Park, is consistent with their conservation and enhancement, and meets the needs of the Park's communities" (p. 46).
Second, each heading is then further divided into a series of sub-themes, and in turn, specific strategic objectives (or outcomes intended by 2030) are formulated. In the case of the living and working in the Park heading, the plan establishes five sub-themes. ${ }^{2}$ The specific strategic objectives (or outcomes) of two of these subthemes are summarised in Table 6 by way of illustration.

Third, seven Priorities for Action (Fig. 3) are identified. These are intended to have a particularly significant impact upon the realisation of the overall management goals of the Park. They also go someway toward the provision of clearer guidance as to how the management principles should be understood. They have been generated through a process of extensive consultation and discussion between the National Park Authority and its partners.

Fourth, for each of the (seven) priority areas a specific action programme is set out. This programme explains 'why' the proposal is deemed a priority, 'what' work/action is included, 'how' it contributes to national strategies and the Plan's strategic objectives (i.e. headings in Fig. 3), and 'what' will be achieved within 5 years. For example, the priority Making Housing More Affordable and

\footnotetext{
2 These sub-themes are-sustainable communities; economy and employment; housing; transport and communication; and waste management.
} 
Table 6

Examples of specific strategic objectives for two sub-themes under the Living and Working in the Park heading

\begin{tabular}{|c|c|}
\hline $\begin{array}{l}\text { Conserving and Enhancing the } \\
\text { Park }\end{array}$ & 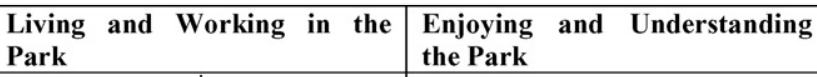 \\
\hline & $\downarrow$ \\
\hline Sub-Theme & Specific Strategic Objectives \\
\hline \multirow[t]{8}{*}{ Economy \& Employment } & $\begin{array}{l}\text { Create conditions conducive to business growth and investment that } \\
\text { are consistent with the special qualities of the Park and its strategic } \\
\text { location. }\end{array}$ \\
\hline & $\begin{array}{l}\text { Encourage entrepreneurship, especially in young people and in sectors } \\
\text { which complement the special qualities of the Park. }\end{array}$ \\
\hline & Promote 'green business' opportunities. \\
\hline & $\begin{array}{l}\text { Promote opportunities for economic diversification across all areas of } \\
\text { the Park. }\end{array}$ \\
\hline & Address barriers to employment uptake. \\
\hline & Raise the profile and excellence of local produce and services. \\
\hline & $\begin{array}{l}\text { Promote access to education and vocational training at all levels } \\
\text { across the Park }\end{array}$ \\
\hline & $\begin{array}{l}\text { Ensure a match between training provision and current/ future skills } \\
\text { needs. }\end{array}$ \\
\hline \multirow[t]{5}{*}{ Sustainable Communities } & $\begin{array}{l}\text { Encourage a population level and mix in the Park that meets the } \\
\text { current/ future needs of its communities and businesses. }\end{array}$ \\
\hline & $\begin{array}{l}\text { Make proactive provision to focus settlement growth in the main } \\
\text { settlements and plan for growth to meet community needs in other } \\
\text { settlements. }\end{array}$ \\
\hline & $\begin{array}{l}\text { Promote provision of local services that meet the needs of } \\
\text { communities through Community Planning and other community } \\
\text { development initiatives. }\end{array}$ \\
\hline & $\begin{array}{l}\text { Strengthen the capacity of local communities and encourage } \\
\text { community development building on existing networks, expertise and } \\
\text { experience. }\end{array}$ \\
\hline & $\begin{array}{l}\text { Promote community involvement and more inclusive representation in } \\
\text { the management of the National Park. }\end{array}$ \\
\hline
\end{tabular}

Table 7

Themes and actions associated with the Making Housing More Affordable and Sustainable priority for action

\begin{tabular}{|l|l|l|l|}
\hline \multicolumn{4}{|c|}{ Priorities for Action (x7) } \\
\hline $\begin{array}{l}\text { Example: Making Housing More Affordable and Sustainable } \\
\text { Increasing supply and }\end{array}$ & $\begin{array}{l}\text { Effective co-operation } \\
\text { and co-ordination }\end{array}$ & $\begin{array}{l}\text { Improving quality and } \\
\text { sustainability }\end{array}$ & $\begin{array}{l}\text { Effective land } \\
\text { infrastructure }\end{array}$ \\
\hline & \\
\hline Actions : & record local community/ housing market preferences \\
& increase the supply of quality, affordable private rented properties and privately owned housing \\
for rent & $\begin{array}{l}\text { use the full range of low cost home ownership mechanisms } \\
\text { review the impact of second and holiday homes, and } \\
\text { continue support for local authorities who are considering or re-applying for pressured area status. }\end{array}$
\end{tabular}

Sustainable is sub-divided into four themes. ${ }^{3}$ For each theme, specific actions are detailed. These include identifying existing relevant information, undertaking assessments/surveys/audits, establishing effective advisory mechanisms, and devising specific management plans. Collectively, the seven priorities for action possess some 22 themes and are associated with in excess of 150 individual manage-

\footnotetext{
${ }^{3}$ Increasing supply and accessibility; effective co-operation and co-ordination; improving quality and sustainability; effective land and infrastructure.
}

ment actions/prescriptions. Table 7 demonstrates this structure for just one priority for action.

\section{Monitoring and review}

A complex system of monitoring and review is planned. The individual work programmes for each priority are to be monitored, along with the extent to which the Park's four aims are being collectively achieved. While an annual report will monitor the input and activities of partners in relation to the priorities for action, the outcomes will be monitored over a 5-year period. This will 
involve identifying measurable indicators (in conjunction with the key partners), which in turn will inform the review of the National Park Plan. Existing priorities for action will then be continued, modified or replaced for a further 5-year period, depending upon the level of progress made and changing circumstances. The longer term management of the Park will be monitored and reviewed through a five-yearly Update to the State of the Park Report. A first State of the Park Report has already been prepared (CNPA, 2006e). It draws together existing information on the current state of the Park's resources (natural, cultural, visitor and recreational, socioeconomic), and as such provides a baseline for future monitoring purposes. Again, in order to monitor change in the state of the Park, a set of indicators are to be devised (involving relevant stakeholders) to reflect the Park's aims. Overall, the monitoring and review process focuses on pressures affecting the Park, the current state of the Park's resources, impacts on the Park, and management responses; a so-called Pressure-State-Impact-Response model (CNPA, 2007a).

In order to comply with the Environmental Assessment of Plans and Programmes (Scotland) Regulations 2004, a process of Strategic Environmental Assessment (SEA) has also been undertaken. The resulting Environmental Report was distributed as part of the Draft Park Plan consultation process. Importantly, the assessment appears to have had a significant bearing on final plan preparation. For example, whilst the Daft Plan states:

"Overall, the objectives of the Draft Park Plan are considered to have a positive effect on the environment, and there are no likely negative effects identified" (CNPA, 2006f, p. 3),

the adopted version of the Park Plan takes a more cautionary view by suggesting that:

"The assessment has shown that the plan as a whole is unlikely to have an adverse impact on the environment. Although many potential effects remain uncertain at this strategic level, the plan is likely to have a positive effect on the environmental resources in the area" (CNPA, 2007c, p. 16)

\section{The Cairngorms National Park: towards the delivery of sustainable development?}

The advent of National Parks in Scotland has become inextricably linked with the need to incorporate sustainable development objectives in the management of valued areas of rural heritage. As such, the National Parks (Scotland) Act endorses the principles behind the recent Planning and etc. (Scotland) Act, 2006 4 and IUCN guidance for the management of inhabited landscapes. To all intents and purposes, Scotland, has introduced Category V Protected Landscape/Seascape designations, but preferred to call them national parks. In adopting Category V guidelines (IUCN, 2002), the Act seeks to manage at the interface between people and nature, stresses the role of a dominant management aim (conservation) in situations of conflict, and promotes a partnership approach to management.

To a certain extent, the integration of sustainable development objectives within the national park approach is based on a wider recognition of the failure of those initiatives which have maintained a faith in environmental elitism. According to Powell et al. (2002) "the primary concern is to avoid a 'preservation' ethos, whereby landscapes are stopped from evolving” (p. 282). Instead they advocate a 'virtuous circle' in which policies promote social and economic activ-

\footnotetext{
4 “... Scottish Ministers must exercise [Planning] functions with the objective of
} contributing to sustainable development" (Part 1A, 3D(2)). ities conducive to environmental integrity" (ibd.). Similarly, Bishop et al.(1995) note that attitudes towards conservation in national parks are moving away from an isolationist perspective, and are increasingly pursuing integrated environmental management structures which locate national parks within what he refers to as 'the jigsaw of sustainability'.

The direction taken by the Scottish model of national parks can also be viewed within the context of the theoretical shift from 'government' to 'governance' (Little, 2001; Swyngedouw, 2005). In her review of the changing direction of management within UK national parks, Thompson (2005) states that the act of 'governing' is increasingly coming to "rely on networks of interconnected actors from the public, private and voluntary sectors rather than a hierarchy dominated and defined by the central state" (p. 323). What has emerged, according to Thompson, is the development of governmentalities "that rely on 'government through community' and the development of governance 'partnerships' that transcend the public/private/voluntary sector divides" (p. 327). Such an approach is also now firmly embedded in the Scottish planning process and is a dominant component of the emerging Scottish national park model. For example, PAN 81 (Scottish Executive, 2007) gives specific advice to Local Authorities on how to engage with communities.

In the Cairngorms National Park, a shared vision, management objectives and a strategic framework have recently been formulated through a finalised Park Plan. Only through time, will it become apparent whether or not the various partners will be able to deliver a shared implementation strategy. Our view is that the management of the Cairngorms National Park, as outlined in its Park Plan, may be stronger in its intent than in the means to deliver. In the remainder of the paper we present this argument with reference to the wider literature on rural management and public policy.

First, the role of the Cairngorms National Park Authority is essentially that of an enabler or facilitator. It corresponds to Edwards et al.'s (2000) facilitative partnership. It is discussion and policyfocused and seeks to enable through strategic engagement. The overall success of the Cairngorms National Park will therefore depend on the Authority's ability to not only bring partners together (which it appears to have achieved so far) but importantly to keep them together during implementation. This will not be an easy task. Notwithstanding Geddes' (1997) argument that partnerships can be effective in developing a collaborative culture in a locality or region "through their enabling function of mediating and negotiating common perspectives among different interests" (p. 107), the CNPA, lacks the powers to make things happen other than through consensus.

Past experience suggests that achieving consensus over vision setting is often possible, but gaining agreement as to how best to bring about that vision and who should be responsible (relative to the other demands on the agencies in question) is likely to be more problematic (Moseley et al., 2001). This is especially true given the number of agencies (see, for example, those listed in Table 4) and communities involved in the management of the Park. The contribution that the Cairngorms Partnership has already made towards collaborative action might prove invaluable (Cairngorms Working Party, 1993) in this regard. As Shortall and Shucksmith (2001) note, a previous history of partnership working can often be helpful in establishing a willingness amongst actors to engage in future activities. However, the Cairngorms Partnership was essentially geared toward land management issues, whilst the Cairngorms National Park is currently bound by a much wider set of aims. Moreover, now that the National Park Plan has been adopted, all public sector partners are expected to have regard to it in terms of the preparation of their respective corporate plans. What will happen however, when the specific remit of a corporate plan conflicts with the 
National Park Plan? It is widely recognised that a major contributor toward ineffective partnership development is when the work of the partnership overlaps with (Edwards et al., 2000) or contradicts (Martin, 1995) the work of individual agencies or actors. An added dimension includes potential conflicts of interest. Some local authority councillors (such as in the Badendoch and Strathspey area of Highland Council) are also members of the Park Authority (The Scotsman, 2004).

More effective management of the Park and the achievement of its aims will only come about if the current plans and practices of partners are challenged. Indeed, if current practices are not being challenged then what is the added value of national park designation and its associated Park Plan? In theory, the National Park Advisory Panel on Joined-Up Government should ensure that individual corporate plans reflect the objectives and priorities of the Park Plan. However, it is unclear what enforcement powers, if any, this Panel will have.

Second, the attainment of National Park aims is unlikely to be achieved by the public sector alone. This is acknowledged by the CNPA and provisions have been established to promote the engagement of non-public bodies, landowners and residents within the Park boundary. However, the extent to which an appropriate level of engagement will be achieved remains an issue of some debate. If the level of involvement witnessed during the public consultation exercise for the Draft Park Plan is anything to go by, the future might be less than encouraging. The report on the consultation process (CNPA, 2006c) states that: "the most challenging sector to engage in consultation was communities" (p. 5) and that "[A]ttendance at the open community consultation meetings was generally low" (ibid.). Where responses were received, they were primarily from well-known individuals rather than groups. According to Edwards et al. (2000), such findings are not unusual. They note that typically public meetings tend to receive low turn out figures with the exception of those who are part of the community elite. The reason for the low level of community interest witnessed within the Cairngorms National Park is unclear. Those who participated may have attended simply to push their own 'self-interest', whilst non-attendance may suggest that the community find it difficult to contribute on equal terms with National Park Authority representatives.

A further concern, which may impact upon the inclusion of broader interests in the management of the Park, relates to partnership form. Moseley (2003) has suggested that the growth of the partnership model has, in many cases, encouraged those local authorities and quangos working at the interface between the state and the community to strive for greater levels of community direction. Yet, it is arguable that the approach to partnership working which has been adopted by the CNPA allows for only low levels of community inclusion. Current structures within the Park are geared primarily to the integration of the activities of existing agencies, whilst limiting the role of communities and voluntary bodies to consultation. This may potentially lead to a rather cosmetic working environment in which a partnership has been established to give the impression of institutional innovation, but which may not ultimately lead to the redistribution of power. The reluctance of public sector agencies to yield power to communities within partnership approaches has been widely commented upon (see for example, Edwards et al., 2001; Ray, 2000; Mackinnon, 2002). Taylor (2007) in particular, has noted that many partnerships rely on topic-based coalitions to represent local interests, but often make little provision for broader community aspirations. The use of target groups in the Cairngorms National Park, such as the National Farmers' Union and the Cairngorms Chamber of Commerce as the conduits of public opinion (Table 4), suggests an unfortunate trend in this direction. If sustainable development is to become more than a public sector responsibility, then there is evidence to suggest that the CNPA needs to move beyond tokenistic partnership structures.

If the CNPA is to move toward an effective model of governance, then any future attempt to increase the political stake of local communities will also need to recognise the potential impediments to inclusion. There are several factors that can affect the level of community involvement attained in any given model. These include: physical geography and local environment; the extent and complexity of programmes and agencies operating in the area; the strength of social capital, the nature of local political relationships and the legitimacy of these new governance structures (Osborne et al., 2004 and Connelly et al., 2006). We would add that continued and increased involvement and co-operation by non-public agencies and other actors (including communities and individuals) can only be assured if they witness tangible results. Accordingly, the outcomes from the first few years in the lifetime of the Park Plan will be crucial to keeping these (and bringing other) groups on board. Where resistance to partnership working has been observed, this has often been the result of the mismatch between raised community expectations and outputs (Shortall and Shucksmith, 2001). Delivering such outputs, in turn, requires a situation in which community desires are "designed-in to local partnerships, not assumed-in" (Lowndes and Sullivan, 2004, p. 70).

Third, we question the level of prescription contained within the National Park Plan. Whilst the use of a tiered hierarchy of strategic action suggests an attempt to fully realise and commit to the strategic vision for the Park, there is a danger that the degree of complexity built into the Plan may limit flexibility and innovation. Central to this debate, is the ability of the Plan to account for change and complexity. Theorists such as Holling (1978) and Lindblom (1959) have long argued for the need to develop incremental and adaptive approaches towards planning and management in complex environments. This issue is likely to be particularly pertinent in the Cairngorms National Park, where an emphasis on the landscape interactions of environment and society will require an approach which can accommodate the complex nature of an ever changing socio-ecological system. It is on this basis that more recent authors such as Briassoulis (1989) and Peterson et al. (2003) have called for a departure from the use of approaches rooted in comprehensive-rationality. Instead, they extend earlier conceptions of 'adaptive planning' and argue for the use of 'scenario' based planning approaches. Typical of this alternative view of environmental planning is the use of contrasting potential futures which can be explored, and subsequently validated, by appropriate stakeholders.

Such a perspective also runs parallel to a faith in broadly defined management partnerships. Critics of the comprehensive-rational model have further questioned the 'assumed' nature of planning decisions. Forester (1999), Freidman (1993) and Healey (1997), amongst others, have argued that the prescriptive nature of many strategic decisions draws on a belief in shared objectives and desired outcomes. Yet, in a multi-stakeholder environment, it is more likely that perceived objectives will vary and that an approach which provides more deliberative accountability may be desirable.

In the light of these debates, we contend that the first Cairngorms National Park Plan may achieve a greater level of success if it allows for a greater level of flexibility and incremental learning than is currently apparent. As a relatively new organisation, the CNPA will need time to develop its institutional structures and operating processes. To date, the planning (decision-making, priority setting) stage appears to have been successfully completed. The question of implementation may require consideration of a more experimental approach. 
The issue of timescale also merits consideration. Given the level of ambition contained within the Plan, will it be possible to deliver real progress within a 5-year period? We would argue that for many strategic priorities, it will take many more years before the results from the specified action programmes become evident. In the meantime, without tangible outcomes at the formal monitoring and review stages it is questionable whether broader support, particularly from the community sector, will be forthcoming. This undoubtedly places the Authority in a difficult position. The need for realistic and appropriate timescales has been reviewed by Beresford and Phillips (2000). They argue that the 'new paradigm for protected areas' needs to move from an emphasis on the short-term to the adaptive planning of more lengthy futures.

Fourth, there are questions surrounding the operational costs of running the Park and the impact that current funding restrictions will have on positive approaches to management. The Cairngorms National Park receives an annual budget of $£ 4.50$ million. This compares favourably with the $£ 1.8$ million received each year by the Northumberland National Park, but is substantially less than the $£ 7.70$ million allocated to the Peak District National Park. As it is expected that the management costs of running the park could be up to $£ 5.5$ million per annum (SNH, 2001), the ability of the CNPA to provide funding for proactive management initiatives could be constrained. This arguably places the Authority in the position of over-reliance on existing rather than new funding streams. This is particularly true of the level of reliance placed upon LEADER+. Although the Authority recognises the dangers of calling upon resources which have no guaranteed future (CNPA, 2007a), it has so far failed to address this uncertainty. A further problem arises in situations where the Authority is forced to compete with authorities out with the Park boundary for funding. As Richards and Satsangi (2004) have argued, such an approach potentially places the delivery of core objectives at risk.

This degree of uncertainty perhaps explains the lack of clarity contained within the Park Plan regarding incentive structures. The Plan openly acknowledges that partnership and consensus alone are unlikely to deliver the aims of the Cairngorms National Park and that guidance, advice and incentives will play a key role. Landowners and communities within the Park boundary in particular, will require encouragement to assist in the delivery of the Cairngorms National Park vision (Barker and Stockdale, 2008). Yet, a close reading of the Plan reveals a lack of explicit reference to the nature of particular schemes and their associated budgets. Such uncertainty is likely to raise genuine concerns about the level of responsibility afforded to wider stakeholders within the Park.

A fifth concern, centres on the impact of the new arrangements for governance within the Park on those areas which lie outside. A dominant theme within studies of protected area management is the potential of national parks to act as 'conservation islands' which seek to displace the potentially negative impacts of human activity outside the park boundary (Agee and Johnson, 1989; West et al., 2006). This is likely to be a complex issue within the Cairngorms National Park. The four local authorities which are expected to work in partnership with the CNPA within the Park boundary are also expected to promote sustainable communities beyond the Park. In particular, they are expected to align their own activities with the terms established by both the Park Plan and the Local Plan. This places these authorities in the position of having to operate a dual system of governance within their respective administrative areas which could well encourage inconsistency in approach. The application of the Sandford Principle is likely to be a significant area of contention as it may well serve to push development deemed inappropriate for the Park to the margins of the Park boundary. A current challenge for the local authority partners operating outside the Park is how they will respond to attempts to alleviate the pressures of second home ownership within the Park. The CNPA ${ }^{5}$ are seeking to review policies on both development control and residency criteria in order to limit the growth of second home ownership. Arguably, such an approach will lead to increased development pressure on margins of the Park. Both Tewdwr-Jones et al. (2002) and Gallent et al. (2002) have noted that second home ownership has presented complex institutional problems in both the English and Welsh national parks. Whilst, the CNPA (2006a) originally recognised that such problems could be an issue within a Scottish context, more recent policy stances have emphasised the need to locate discussion within an understanding of national and international responsibilities.

In addition to concerns over the negative consequences of national park planning and management activity upon neighbouring areas, concerns also exist where landscape boundaries are inconsistent with administrative units (Brown, 2003). A particularly pertinent and on-going issue relates to the exclusion of Highland Perthshire from the national park boundary. While the area was originally recommended for inclusion within the park, it was excluded by the Scottish Executive when the boundary was finally approved. The Executive used the administrative boundary of Perth and Kinross Council to define the Park's southern limits. The exclusion of Highland Perthshire meant that some Cairngorms mountains (for example, Carn Liath) lay outside the Park Since then there have been numerous calls for a boundary change (The Scotsman, 2007a,b,c), culminating in a private members' bill brought by John Swinney (a local Member of Scottish Parliament). Finally in March 2008 a Ministerial decision was taken to extend the Park boundary to include Highland Perthshire (see Fig. 2) and review the Park's organisation and operating powers, including its planning powers.

Sixth, the approach adopted to reconcile different Park aims and priorities may prove problematic. In multifunctional protected areas, specifically those which contain a socio-economic dimension, spatial zoning is often advocated as a means of reconciling resource use tensions (IUCN, 2002). Wells and Brandon (1992) have argued that such an approach is often effective in areas where boundaries or management priorities are likely to be contested. On this basis, McCarthy et al. (2002) have drawn attention to the popularity of the approach within Europe and the USA. Yet, the current Park Plan has rejected this approach in favour of a case-bycase assessment method. Thus, the CNPA (2007a) are advocating "an objective led approach set out across the whole Park, rather than setting out prescriptions for different management zones" (p. 20). This approach seems somewhat at odds with the comprehensive basis of the Park Plan. Whilst we argue for a greater degree of flexibility in strategic decision making, we remain sceptical of the lack of spatial emphasis within the current approach. This largely results from the degree of landscape complexity which exists in the Cairngorms. As Gordon et al. (1998), Watson (1996) and Gimingham (2002), have discussed, the Cairngorms is an area of great landscape diversity and changing character. Unless the variation is used to guide policy, it is likely that the nature of human/environment interactions in the landscape will not be fully understood. Where previous experiments in multifunctional protected area management have proved

\footnotetext{
5 The Cairngorms National Park Authority sought permission from the Scottish Executive to alter rules so that a change of use from a permanent house to a second or holiday home would require planning permission. The Authority is also seeking the introduction of 'residency criteria'-house applicants must be resident in the Park for at least three years or be working or about to work in the area. A similar policy operates in the Yorkshire Dales National Park (The Scotsman, 2006).
} 
effective, it has been in their ability to provide a spatial frame of reference to partnership members. This it is argued, can improve the link between solution and context, focus debate on key issues, and limit the degree of potential stakeholder conflict (Fayeraband and Borrini, 1996).

\section{Conclusion}

The emergence of national parks in Scotland represents an important development in the evolution of UK national parks. Whilst national parks in England and Wales have their origins in a dominant conservation and recreation ethos, the Scottish model of national park is firmly rooted in the principles of sustainable development. On this basis, the model does much to advance notions of the 'landscape' based approach advocated by the IUCN (2002). Rather than seek to embody an environment lacking human influence, the Scottish interpretation of national parks openly accounts for the role of people in shaping landscape character. Yet, although the provisions established to promote national parks in Scotland provide a statutory responsibility for national parks to deliver sustainable development, it is not clear how this will be achieved. The National Parks (Scotland) Act 2000 outlines the strategic purpose of national parks, but allows for a significant degree of local discretion. Consequently, the success of the Scottish approach in meeting sustainable development objectives will be dependent upon the manner in which national park planning and management tasks are interpreted by the national park authorities.

This paper has provided a case study review of how national park aspirations and responsibilities are currently being understood within the Cairngorms National Park. This review goes someway toward an appreciation of the relative merits, or otherwise, of the discretionary approach. Ultimately, it suggests that whilst the Scottish model allows for a significant level of innovation and local level experimentation, if these opportunities are to be advanced, then a greater level of guidance and support from the centre will be required. Currently, the approach being adopted in the Cairngorms suggests an awkward relationship between institutional uncertainty and administrative prescription. Although, there seems to be a degree of consensus within the Park that economic growth needs to be linked to the ecological character of the landscape, there is much uncertainty as to the exact roles and responsibilities of those trusted with planning and management. Central to the approach adopted by the CNPA is a belief in the principle of management by partnership. However, there are genuine concerns over the ability of the CNPA to develop a partnership with existing statutory bodies which allows for the sharing of alternative views and perceptions, but at the same time is likely to result in consensus. Similarly, whilst the partnership principle is extended to non-statutory bodies, it is as yet unclear how much power they are to be afforded and the extent to which they are viewed as central rather than peripheral players. In a structure that lacks clear pathways for decision making, it is likely that such challenges will need to be met through incremental learning. This is likely to prove difficult however, as the National Park Plan has placed an emphasis on detail and prescription rather than on management innovation. Much of the future work of the various partnerships is therefore already significantly constrained. A limited central budget and reliance upon existing funding streams are also likely to limit progress.

In the light of these comments, we conclude that reliance upon a model characterised by local level discretion brings with it a greater commitment for guidance and support from the centre. Based on current experiences within the Cairngorms National Park, it would appear there is a need to provide a fuller level of direction in the formation and operation of partnerships. This could potentially take the form of funded pilot schemes with a particular set of partners or could instead be centred on thematic areas of concern. Arguably, the development of a greater level of confidence within the partnership approach may encourage a more simplified method of strategic planning and the emergence of more experimental approaches to national park management. Only then is the Scottish model of national park likely to deliver sustainability to multifunctional landscapes.

\section{Acknowledgements}

The authors are grateful to the two anonymous referees for their valuable comments and to Graham Bowden (Manchester University) for preparing the maps.

\section{References}

Agee, J.K., Johnson, D.R., 1989. Ecosystem Management for Parks and Wilderness. University of Washington Press, Washington DC.

Barker, A., Stockdale, A., 2008. Out of the wilderness? Achieving sustainable development within Scottish National Parks. J. Environ. Manage. 88 (1), 181-193.

Beresford, M., Phillips, A., 2000. Protected landscapes-a conservation model for the 21st Century. George Wright Forum 17 (1).

Bishop, K., Phillips, A., Warren, L., 1995. Protected forever? Factors shaping the future of protected areas policy. Land Use Policy 12 (4), 291-305.

Bishop, K., Green, M., Phillips, A., 1998. Models of National Parks. SNH, Perth.

Briassoulis, H., 1989. Theoretical orientations in environmental planning: an inquiry into alternative approaches. J. Environ. Manage. 13 (4), 381-392.

Brown, K., 2003. Integrating conservation and development: a case of institutional misfit. Front. Ecol. Environ. 1 (9), 479-487.

Brown, J., Mitchell, N., Beresford, M. (Eds.), 2005. The Protected Landscape Approach: Linking Nature, Culture and Community. IUCN, Gland.

Cairngorms National Park Authority, 2006a. A Draft Plan for the Future: Looking to 2030. Grantown-on-Spey.

Cairngorms National Park Authority, 2006b. A Draft Plan for the Future: Priorities for Action 2007-2012. Grantown-on-Spey.

Cairngorms National Park Authority, 2006c. Consultation Report on the Cairngorms National Park Plan. Grantown-on-Spey.

Cairngorms National Park Authority, 2006d. Draft Cairngorms National Park Local Plan. Grantown-on-Spey.

Cairngorms National Park Authority, 2006e. State of the Park Report 2006. Grantown-on-Spey.

Cairngorms National Park Authority, 2006f. A Draft Plan for the Future: Strategic Environmental Assessment Environmental Report. Grantown-on-Spey.

Cairngorms National Park Authority, 2007a. Cairngorms National Park Plan 2007. Grantown-on-Spey.

Cairngorms National Park Authority, 2007b. Cairngorms National Park Local Plan (on deposit). Grantown-on-Spey.

Cairngorms National Park Authority, 2007c. The Strategic Environmental Assessment Statement on the Cairngorms National Park. Grantown-on-Spey.

Cairngorms Working Party, 1993. Common Sense and Sustainability: A Partnership for the Cairngorms. HMSO, Edinburgh.

Connelly, S., Richardson, T., Miles, T., 2006. Situated legitimacy: deliberative arenas and the new rural governance. J. Rural Stud. 22 (3), 267-277.

Countryside Commission for Scotland, 1990. Management of the Mountain Areas of Scotland, Perth.

Crabtree, J.R., 1991. National Park designation in Scotland. Land Use Policy, 241-252.

Dickinson, G., 1991. National Parks: Scottish needs and Spanish experience. Scott. Geogr. Mag. 107, 124-129.

Dilsaver, L.M. (Ed.), 1997. America's National Park System: the Critical Documents. Rowman and Littlefield, Lanham.

Dower Report (1945) National Parks in England and Wales. Cmd 6628. HMSO, London.

Dower, M., 1999. Experience from National Parks elsewhere. In: National Parks for Scotland: Conference Proceedings: Developing Proposals for National Parks. Scottish Natural Heritage, Perth.

Edwards, B., Goodwin, M., Pemberton, S., Woods, M., 2000. Partnership Working in Rural Regeneration. Governance and Empowerment? The Policy Press, Bristol.

Edwards, B., Goodwin, M., Pemberton, S., Woods, M., 2001. Partnerships, power, and scale in rural governance. Environ. Plann. C 19, 289-310.

Fayeraband, G.B., Borrini, G., 1996. Collaborative Management of Protected Areas: Tailoring the Approach to the Context. IUCN, Gland.

Ferguson, M., Forster, J., 2005. Establishing the Cairngorms National Park: lessons learned and challenges ahead. In: Thompson, D.B.A., Price, M.F., Galbraith, C.A. (Eds.), Mountains of Northern Europe: Conservation, Management, People and Nature. TSO Scotland, Edinburgh, pp. 275-290 (Chapter 26).

Forester, J., 1999. The Deliberative Practitioner: Encouraging Participatory Planning Processes. MIT Press, London. 
Freidman, J., 1993. Towards a non-Euclidean mode of planning. J. Am. Plann. Assoc. $59,482-484$.

Gallent, N., Mace, A., Tewdwr-Jones, M., 2002. Policy Advice on Second Homes in Rural Areas. Countryside Agency, Cheltenham.

Geddes, M., 1997. Partnership against poverty and exclusion? Local regeneration strategies and excluded communities in the UK. The Policy Press, Bristol.

Gimingham, C., 2002. The Ecology, Land Use and Conservation of the Cairngorms. Packard Publishing, Chichester.

Gordon, J.E., Thompson, D., Haynes, V., Brazier, V., MacDonald, R., 1998. Environmental sensitivity and conservation management in the Cairngorms Mountains, Scotland. Ambio 27 (4), 335-344.

Gordon, J.E., Dvorak, I.J., Jonasson, C., Josefsson, M., Kocianova, M., Thompson, D., 2002. Geo-ecology and management of sensitive montane landscapes. Geografiska Annaler 84 (3-4), 193-203.

Hall, P., 1992. Urban and Regional Planning. Routledge, London.

Healey, P., 1997. Collaborative Planning: Shaping Places in Fragmented Societies. Macmillan, London.

Hobhouse Report, 1947. Report of the National Parks Committee (England and Wales). Cmnd 7121. HMSO, London.

Holdgate, M., 1992. Protected areas in the future: The implications of change and the need for new policies. In: Paper Presented at the IVth World Congress on National Parks and protected Areas. IUCN Caracas.

Holling, C.S., 1978. Adaptive Environmental Assessment and Management. Wiley and Sons, Chichester.

Illsley, D., Richardson, T., 2004. New National Parks for Scotland: Coalitions in conflict over the allocation of planning powers in the Cairngorms. J. Environ. Plann. Manage. 47 (2), 219-242.

International Union for the Conservation of Nature-The World Conservation Union, 1992. Parks for Life. Report of the IVth World Congress on National Parks and Protected Areas, Caracas. IUCN, Gland.

International Union for the Conservation of Nature-The World Conservation Union, 1994. Guidelines for Protected Management Strategies. Gland.

International Union for the Conservation of Nature-The World Conservation Union, 2002. Management Guidelines for IUCN Category V Protected Areas. Gland.

International Union for the Conservation of Nature-The World Conservation Union, 2004. Vth World Parks Congress: Durban Action Plan. Gland.

Lindblom, C., 1959. The science of 'muddling through'. Public Admin. Rev. 19 (2), 79-88.

Little, J., 2001. New rural governance? Prog. Hum. Geogr. 25 (1), 97-102.

Lowndes, V., Sullivan, H., 2004. Like a horse and carriage or a fish on a bicycle: How well do local partnerships and public participation go together? Local Govern. Stud. 30 (1), 51-73.

MacEwan, A., MacEwan, M., 1982. National Parks: Conservation or Cosmetics. George Allen and Unwin, London.

MacKay, J., 2005. People, recreation and the mountains with reference to the Scottish Highlands. In: Thompson, D.B.A., Price, M.F., Galbraith, C.A. (Eds.), Mountains of Northern Europe: Conservation, Management, People and Nature. TSO Scotland, Edinburgh, pp. 127-136 (Chapter 11).

Mackinnon, D., 2002. Rural governance and local involvement: assessing statecommunity relations in the Scottish Highlands. J. Rural Stud. 18 (3), 307-324.

Martin, A., 1995. Partnership for local environmental action: observations on the first two years of Rural Action for the Environment. J. Environ. Plann. Manage. 38 (2), 149-165.

McCarthy, J., Lloyd, G., Illsley, B., 2002. National Parks in Scotland: balancing environment and economy. Eur. Plann. Stud. 10 (5), 665-670.

Moseley, M., Cherrett, T., Cawley, M., 2001. Local partnerships for rural development, Ireland's experience in context. Irish Geogr. 34 (2), 176-192.

Moseley, M., 2003. Local partnerships for rural development, the European experience. CABI, Oxford.

Nash, J., 1967. Wilderness and the American Mind. Yale, New Haven.

National Parks (Scotland) Act, 2000. Scottish Parliament, Edinburgh.

O'Brian, B., 1999. Our National Parks and the Search for Sustainability. University of Texas Press, Austin.

Osborne, S., Williamson, A., Beattie, R., 2004. Community involvement in rural regeneration partnerships: exploring the rural dimension. Local Govern. Stud. 30, $156-181$.

Peterson, G.D., Cumming, G.S., Carpenter, S.R., 2003. Scenario planning: a tool for conservation in an uncertain world. Conserv. Biol. 17 (2), 358-366.
Phillips, A., 2005. Landscape as a meeting ground: Category V protected landscapes/seascapes and world heritage cultural landscapes. In: Brown, J., Mitchell, N., Beresford, M. (Eds.), The Protected Landscape Approach: Linking Nature, Culture and Community. IUCN, Gland.

Phillips, A., Clarke, R., 1996. Our landscape from a wider perspective. In: Nelson, J.G. Serafin, R. (Eds.), National Parks and Protected Areas: Keystones to Conservation and Sustainable Development. Springer-Verlag, Berlin.

Planning etc. (Scotland) Act, 2006. Scottish Parliament, Edinburgh.

Powell, J., Selman, P., Wragg, A., 2002. Protected areas: reinforcing the virtuous circle. Plann. Pract. Res. 17 (3), 279-295.

Ramsay Report, 1947. National Parks and the Conservation of Nature in Scotland. Cmnd. 7235, HMSO, Edinburgh.

Ray, C., 2000. Editorial. The EU Leader Programme: Rural Development Laboratory. Sociologia Ruralis 40 (2), 163-171.

Richards, F., Satsangi, M., 2004. Importing a policy problem? Affordable housing in Britain's National Parks. Plann. Pract. Res. 19 (3), 251-266.

Rydin, Y., 1998. Urban and Environmental Planning in the UK. MacMillan, London.

Sandford Committee, 1974. Report of the National Park Policy Review Committee. HMSO, London.

Scottish Executive, 2002. Building Consensus for Rural Development and Planning in Scotland: A Review of Best Practice. Edinburgh.

Scottish Executive, 2007. Community Engagement: Planning with People. Planning Advice Note 81. Edinburgh.

Scottish Natural Heritage, 2001. A New Way of Caring for a Special Place. Edinburgh

Scottish Office, 1991. The Mountain Areas of Scotland: Conservation and Management-Government Response to Countryside Commission Report. Edinburgh.

Shortall, S., Shucksmith, M., 2001. Rural development in practice: issues arising in Scotland and Northern Ireland. Community Dev. J. 36 (2), 122-133.

Shucksmith, M., Lloyd, G., 1983. Rural planning in Scotland: a critique. In: Gilg, A.W. (Ed.), Countryside Planning Yearbook. Geobooks, Norwich, pp. 103-128.

Shucksmith, M., Chapman, P., Clark, G., 1994. Disadvantage in Rural Scotland. Rural Forum, Perth.

Shucksmith, M., Chapman, P., 1998. Rural development and social exclusion. Sociologia Ruralis 38 (2), 225-242.

Skinner, S., 1997. Building Community Strengths: A Resource Book on Capacity Building. Community Development Foundation, London.

Swyngedouw, E., 2005. Governance innovation and the citizen: the Janus face of governance-beyond-the-state. Urban Stud. 42 (1), 1991-2006.

Taylor, M., 2007. Community participation in the real world: opportunities and pitfalls in new governance spaces. Urban Stud. 44 (2), 297-317.

Tewdwr-Jones, M., Gallent, M., Mace, A., 2002. Second and Holiday Homes and the Land Use Planning System. Report to the Welsh Assembly Government. University College London.

The Scotsman, 2004. Row erupts over planning for new Cairngorms Park. Friday, 13th February 2004.

The Scotsman, 2006. National Park homes for locals only. Saturday, 20th May 2006

The Scotsman, 2007a. Bid to widen Cairngorms National Park boundaries. Friday, 19th January 2007.

The Scotsman, 2007b. Minister deals blow to national park extension campaign. Thursday, 15th February 2007.

The Scotsman, 2007c. Move to extend national park is rejected by MSPs. Tuesday 6th, March 2007.

Thompson, N., 2005. Inter-institutional relations in the governance of England's national parks: A governmentality perspective. J. Rural Stud. 21 (3), 323-334.

United Nations Commission on Environment and Development, 1987. Our Common Future. Oxford University Press, Oxford.

Warren, C., 2002. Managing Scotland's Environment. EUP, Edinburgh.

Watson, A., 1996. Internationally important environmental features of the Cairngorms, research and main research needs. Bot. J. Scot. 48 (1), 1-12.

Wells, M., Brandon, K., 1992. People and Parks: Linking Protected Area Management with Local Communities. World Bank, Washington DC.

West, P., Igoe, J., Brockington, D., 2006. Parks and people: the social impact of protected areas. Annu. Rev. Anthropol. 35 (25), 1-77.

Zupančič-Vičar, M., 1997. Parks for life: an action plan for the protected areas of Europe. In: Nelson, J.G., Serafin, R. (Eds.), National Parks and Protected Areas: Keystones to Conservation and Sustainable Development. SpringerVerlag, Berlin. 